\title{
THE SYRIAN MEDICAL AID ASSOCIATION: BRITISH PHILANTHROPY IN THE NEAR EAST
}

\author{
by
}

\begin{abstract}
AMALIE M. KASS*
Of all the blessings which England might, out of her abundance impart to the Syrians-the one they most desire and appreciate- is medical skill. ${ }^{1}$
\end{abstract}

The Syrian Medical Aid Association (SMAA), created by British philanthropists and medical men in the 1840s, represents one of the earliest attempts by a secular organization to transmit Western medicine to a part of the world deemed to be in need of assistance. Its founders, convinced of the need for well-trained physicians, drugs, and equipment in Syria and hopeful that the introduction of scientific medicine would facilitate the introduction of other English "blessings", expected long-lasting benefits for the Syrians and closer relations between England and the people of the Near East. Despite their fervour and their certainty of the importance of the cause, they failed to anticipate the difficulties inherent in such ambitious plans and after a few years were forced to terminate their efforts.

The precursors to the SMAA were the agents of the great trading companies, army and navy surgeons and missionaries who had provided occasional medical aid in the "benighted areas" of the world. ${ }^{2}$ However, health care was not the primary purpose of the sponsoring organizations and the incidental aid which was rendered was not expected to have much impact on the lives of the population at large. ${ }^{3}$ Few of the missionaries were medically trained, and in any case they were generally more

- Amalie M. Kass, BA, MEd, Countway Library and Channing Laboratory, Harvard Medical School, Boston, Massachusetts 02115, USA.

\footnotetext{
${ }^{1}$ Prospectus of the Syrian Medical Aid Association, Br. for. med. Rev., 1842, 13: 579-580.

2 The East India Company employed surgeons at several of its stations in India and China. One of these, Alexander Pearson, is credited with introducing vaccination in China in 1805, and another, Thomas Colledge, founded an ophthalmic clinic in Macao in 1827 where he began training natives to treat eye diseases and gradually expanded his services to treatment of other disorders. James S. Dennis, Christian missions and social progress, 3 vols., Edinburgh, Oliphant, Anderson \& Ferrier, 1899, vol. 2, pp. 405-411; A brief account of an ophthalmic institution during the years 1827,28,29,30,31 and 1832 at Macao, by a Philanthropist, Canton, China, 1834 (both at the Library, Wellcome Institute for the History of Medicine).

${ }^{3}$ An exception may be found in the bequest for educational purposes made in 1703 to the Society for the Propagation of the Gospel in Foreign Parts by General Christopher Codrington, Governor of the Leeward Islands. Codrington's will stipulated that students should study "physick and Chirurgery as well as Divinity" so that they might "have the better opportunity of doing good to men's souls whilst they are taking care of their bodies." Codrington College opened in Barbados in 1745, but medicine was never part of the curriculum. Dennis, op. cit., note 2 above, vol. 2, p. 404; Sir Kenneth Stuart, private communication to the author.
} 
interested in saving souls than bodies. ${ }^{4}$ Probably this was just as well since medical treatment, based as it was on humoral theories that demanded bleeding and purging, was only marginally useful at best and frequently detrimental.

Dr Peter Parker's experiences as physician and missionary in China more directly influenced the Englishmen who founded the SMAA. Parker, an American who had received degrees in medicine and divinity from Yale, was the first person to combine medicine with missionary work to any significant extent. ${ }^{5}$ In 1834 , Parker was sent by the American Board of Commissioners for Foreign Missions to Canton where he established a hospital and began to train native assistants. His success as a doctor, especially in the treatment of eye diseases, coupled with his personal piety and devotion to the Gospel, made him an effective spokesman for Western medicine and for Christianity. Within a short time, he was engaged in the formation of a society of local British and American merchants and missionaries who wanted to attract additional medical men to China. ${ }^{6}$ The members of the Medical Missionary Society in China viewed medicine as a wedge for the dissemination of the Christian religion and the "good works of philanthropy", but they realized that missionaries who were inadequately trained in medicine should not try to heal the sick. The Canton-based group wanted English and American missionary societies to select good doctors and send them to China where the local society would direct their activities and assist them financially. ${ }^{7}$ Dr Parker's example and the efforts of the Medical Missionary Society successfully stimulated interest in Britain and the United States and led to large numbers of medical missionaries going to China over the next hundred years. ${ }^{8}$

The outbreak of hostilities between China and Britain in the First Opium War forced Dr Parker to leave Canton in 1840, first for Macao and then for the United States where he delivered sermons and speeches describing his work in China and

\footnotetext{
${ }^{4}$ This is not the place to attempt an inventory of missionaries who had medical training, but is useful to note that Danish missions to India in 1730 and 1747 and Moravian missions to Persia in 1747 included medical men. At the end of the eighteenth century, the Baptist Missionary Society and the London Missionary Society employed doctors, though with little success. Robert Mayor, who went to Ceylon in 1817 for the Church Missionary Society, had been trained in medicine. In 1828, Dr Carl Gutzlaff began his medical and missionary work in Siam and along the coast of southern China. Dr H. S. Ford, who went to New Zealand in 1836, was instructed to devote himself primarily to medicine. H. G. Anderson, 'History of C.M.S. medical missions', unpublished MS, pp. 10-23; The London Society for the Promotion of Christianity among the Jews and the American Board of Commissioners for Foreign Missions sent agents to Syria and the Holy Land during the second decade of the nineteenth century. Some of them had been trained in medicine, though religious conversions were their primary purpose. A. L. Tibawi, American interests in Syria 1800-1901, Oxford, Clarendon Press, 1966, pp. 16-19, 34, 61-62.

${ }^{5}$ For a biography of Parker see Edward V. Gulick, Peter Parker and the opening of China, Cambridge, Mass., Harvard University Press, 1973.

${ }^{6}$ Suggestions for the formation of a medical missionary society offered to the consideration of all Christian nations, more especially to the kindred nations of England and the United States of America, signed by Thomas R. Colledge, Peter Parker, and E. C. Bridgman, Canton, 1836. For Colledge see note 2 above. Rev. Elijah Coleman Bridgman founded the American Board mission station in Canton. See Gulick, op. cit., note 5 above, pp. 26, 44-46.

${ }^{7}$ The Medical Missionary Society in China with minutes of proceedings, officers, etc. Also an appendix containing a brief account of an Opthalmic Institution at Macao for the years 1827, 1828, 1829, 1830, 1831 , 1832, London, Royston \& Brown, 1839.

8 In 1933, for instance, there were about 300 medical missionaries in China, serving approximately 235 mission hospitals that treated more than 1,000,000 patients a year. Dr William Lennox, 'Medical missions', in Orville A. Pelty (editor), Layman's foreign missions, etc. cited in Gulick, op. cit., note 5 above, p. 206.
} 
appealing for support. Parker's home stay was interrupted by a four-month fund-raising tour of England, Scotland, and France. In Britain, the Archbishop of Canterbury, the Duke of Sussex, and the Duke of Wellington headed the list of notables who gave him their approbation. ${ }^{9}$ He was well received by eminent physicians and surgeons, the heads of the missionary societies, lay evangelicals, and philanthropists. He published and circulated a pamphlet that promoted foreign medical missions. Parker visited Guy's Hospital, where he was pleasantly surprised to see some of his Chinese patients in portraits which had been recently acquired by the hospital's museum. ${ }^{10}$ The crowning event of his stay in Britain was a large public meeting on behalf of the Medical Missionary Society in China, held in Exeter Hall, London, on 15 July 1841. Parker's address was followed by a series of resolutions supporting his work. ${ }^{11}$

Parker's message regarding the possibilities for evangelizing and the need for Western-style medicine in China soon contributed to the creation of two organizations which incorporated his recommendations. In November 1841, the Edinburgh Association for Sending Medical Aid to Foreign Countries was founded with Dr John Abercrombie, Parker's host in Edinburgh and a leader in the Scottish medical world, as its foremost personality. ${ }^{12}$ (Its name was subsequently altered to the Edinburgh Medical Missionary Society.) Initially, the recipients of Scottish philanthropy were Dr Parker's Medical Missionary Society in China and the newly founded Syrian Medical Aid Association. ${ }^{13}$ The former, being closely allied with the missionary societies, depended on them to select doctors and in some cases to pay for medical training. The SMAA, however, was an autonomous organization.

\footnotetext{
${ }^{9}$ Peter Parker, Journal 8B, Peter Parker Collection, Yale Medical Library, New Haven, Conn., passim, especially 18 and 19 May 1841; Gulick, op cit., note 5 above, pp. 102-106; Anderson, op. cit., note 4 above, p. 27.

${ }^{10}$ Parker, Journal 8B, op. cit., note 9 above, 1 June and 12 July 1841 . The oil portraits done in Canton by the Chinese artist Lam Qua and his co-workers are notable for their remarkable presentation of gross tumours, many of which were successfully removed by Parker. Of 115 known Lam Qua paintings, eighty-six are presently owned by the Yale Medical Library; twenty-three remain in the Gordon Museum at Guy's Hospital, London; five are at the Johnson Art Museum, Cornell University; and one is displayed at the Countway Library, Harvard Medical School, Boston. See Gulick, pp. 149-156 and note 31, pp. 244-5; Sander L. Gilman, 'Lam Qua and the development of a westernized medical iconography in China', Med. Hist., 1986, 30: 57-69. No one who has seen the Lam Qua portraits is likely to forget them, not only because of the grotesque afflictions of the patients but also because of the style and ability of the artist.

${ }^{11}$ Meeting in behalf of the Medical Missionary Society in China held in Exeter Hall Building, London, 15 July 1841, in Peter Parker, Statements respecting hospitals in China preceded by a letter to John Abercrombie, M.D., V.P.R.S.E., Glasgow, Maclehose, 1842. See also William W. Cadbury, 'Friends in China', Bull. Fr. Hist. Assoc., 1937, 26 (2): 86-87. Unfortunately, the British were more lavish with their praise than with their pocketbooks. The war with China, financial troubles, and the habitual reluctance of the British to contribute money to American appeals meant that despite his warm welcome and many speaking engagements, Parker did not raise much money in England. See Gulick, op. cit., note 5 above, p. 103; and Thomas Hodgkin to "My dear Friend" [Dr. Parker], 7 August 1841, Hodgkin MSS, 9:247. There are microfilm copies of the Hodgkin papers at Friends' House Library, London, and at the Countway Library and in the possession of Dr Edward H. Kass and myself.

${ }_{12}$ John Lowe, Medical missions, their place and power, Edinburgh, Oliphant, Anderson \& Ferrier, [1895], pp. 201-204; for John Abercrombie, MD, (1781-1844) see DNB, I, 37-38.

${ }^{13}$ Fourth annual report of the Edinburgh Medical Missionary Society, Edinburgh, 1846. I am grateful to the Council for World Mission for permission to cite this source and others at the School of Oriental and African Studies, University of London, referenced as CCWM 01/2, Pams. 35.
} 
The precise genesis of the SMAA is not certain, but the strong link between its organizers and Peter Parker and the coincidence with Parker's visit to London suggest his strong influence. Parker's Journal mentions many of the subsequent officials of the SMAA, including Rev. Baptist Noel, Sir James Clark, MD, Sir Henry Halford, MD, and Thomas Hodgkin, MD. At the Exeter Hall meeting, Hodgkin commended the Medical Missionary Society for emulating "the Saviour himself, who, while seeking first and chiefly, the good of the soul, did not fail to care for the bodies of men." Hodgkin pointed out the fortuitous circumstance whereby Christians of several nations were united in the enterprise and he included praise for his "friend Dr. Parker" in his remarks. ${ }^{14}$

Most frequently identified with the origins of the SMAA is Sir Culling Eardley Smith. There is no direct evidence that he met Parker, but Eardley Smith's career and propensities make it likely; it is almost certain that he was familiar with Parker's ideas and accomplishments. Sir Culling was a man of considerable wealth and prestige. His mother was descended from a Jew, Gideon Sampson, and, although Sir Culling was an evangelical Christian, he never disavowed his heritage. Indeed, it seemed to stimulate his concern for poor Jews and his interest in those parts of Syria which were holy to Jews and Christians. ${ }^{15} \mathrm{He}$ had a record of involvement in liberal causes such as anti-slavery and the Aborigines Protection Society, plus a strong allegiance to the London Missionary Society and the London Society for the Promotion of Christianity amongst the Jews (also referred to as the London Jews Society). ${ }^{16}$ Sending doctors abroad to render medical aid, promote Christianity, and demonstrate the advantages of Western civilization was an appealing notion to him.

Parker's new friends and admirers were also influenced by three contemporary currents in English society. A strong sentiment of philanthropy and reform led many middle-class Britons to join an endless number of committees and societies that were created to eliminate obvious social ills at home and overseas. The philanthropists spent endless hours organizing, propagandizing and politicking for the abolition of slavery, reform of the penal system, improved conditions for factory children and chimney sweeps, schools, soup kitchens, temperance, reduced use of tobacco, etc. Though they seldom addressed the underlying causes of social distress, they had enormous confidence in their ability to effect improvements through rational promotion of gradual social change. Implicit in this humanitarianism was a belief that the morals and standards of their own class were worthy of imitation by the less advantaged, and an equally strong certainty that the arts and sciences, technology and industry of the Western European nations, and especially of Great Britain, placed them at the forefront of civilization. From their viewpoint, modern medicine was a prominent accomplishment of that society and should be shared with less fortunate nations. ${ }^{17}$

\footnotetext{
14 Meeting in behalf of the Medical Missionary Society, etc., and Cadbury, both cited in note 11 above.

15 DNB, VI, 316-317; Louis Loewe (editor), Diaries of Sir Moses and Lady Montefiore, facsimile of the 1890 edition, Jewish Historical Society of England and the Jewish Museum, 1983, vol. 2, pp. 33, 84, $107,120$.

${ }^{16}$ Life of William Allen, with selections from his correspondence, Philadelphia, H. Longstreth, 1847, vol. 2, p. 386; Culling Eardley Smith to Rev. J. J. Freeman, 14 April 1840, 25:46, note 11 above; W. T. Gidney, The history of the London Society for Promoting Christianity Amongst the Jews from 1809 to 1908, London, The Society, 1908, pp. 41-42. Subsequent to helping form the SMAA, in 1846 Sir Culling was a founder of the Evangelical Alliance, a Protestant organization to promote religious liberty worldwide.
} 
The SMAA was also affected by the evangelicalism which had spread from the dissenting sects to include many Anglican clergy and laymen. Belief in personal redemption through Jesus and in the sanctity of His Word led to an intense commitment to bring the Gospel to the unsaved. From this evangelical spirit came a profusion of school and Bible societies determined to instruct the poor at home and of missionary societies which sent their agents abroad to convert the heathen. No one was exempt from the efforts of the evangelicals, including the Jews for whose particular conversion the London Society for the Promotion of Christianity had been created. ${ }^{18}$ Many of the social reformers were also evangelicals, thereby reinforcing the often-expressed sentiment that all of God's creatures were worthy of their beneficence. Responsibility for spreading both civilization and Christianity was not to be taken lightly. For the evangelicals too, medicine was directly related to their purposes. Hodgkin struck a familiar chord at Exeter Hall; the evangelicals knew well that Jesus had healed the sick and cured the blind.

Finally, increased British interest and involvement in the lands of the eastern Mediterranean played a part in directing the energies of the men who started the SMAA. As part of the Ottoman Empire, the area generally referred to as Syria was caught between the weak Sultan in Constantinople and his vassal Mehmet Ali, who ruled in Egypt and had conquered Syria in 1832. The British Foreign Office had been heavily engaged in complicated balance-of-power politics in Syria, simultaneously bolstering the feeble Turks out of fear of Russian expansion, thwarting the ambitions of the French and the Roman Catholic church, protecting trade routes to Persia and India, and promoting British commerce locally. As part of this policy, the British supported the Sultan in his desire to eliminate the Egyptian presence in Syria. Through a combination of diplomacy and armed force Britain had assisted in the expulsion of Mehmet Ali, organizing a naval bombardment of Beirut in the autumn of $1840 .^{19}$

British interest in Syria was not confined to international politics. Although an American missionary society had sent agents to the area as early as 1819 and was established in Beirut by 1823, representatives of the Church Missionary Society and of the British and Foreign Bible Society had also visited the region and provided information about the possibilities for religious work among the eastern Christian sects not yet exposed to Protestant teaching. ${ }^{20}$ Traditional devotion toward the land of the Old and New Testaments, coupled with the hope of converting the Jews, added a romantic notion. Dr William Holt Yates was typical of those who were convinced that Britain could extend its influence in the area by helping the Jews return to the land of their fathers. Yates had lived in Syria and in Egypt, where he became a strong critic of Mehmet Ali and of French machinations in the area. His correspondence with the

\footnotetext{
${ }^{17}$ Early in the 1840s, the Aborigines Protection Society, under the leadership of Dr Thomas Hodgkin, wanted to send "a medical person to some portion of the globe ... to administer relief and instruct natives in the practice of his profession" but it lacked sufficient funds. Aborigines Protection Society, England and her Colonies considered in relation to the aborigines, with a proposal for affording them medical relief, n.d.; See also note 24 below.

${ }^{18}$ Gidney, op. cit., note 16 above.

19 M. S. Anderson, The eastern question 1774-1923, London, Macmillan, 1966, pp. 88-109; Asa Briggs, The age of improvement 1783-1867, London, Longman, 1979, pp. 353-35.

${ }^{20}$ Tibawi, op. cit., note 4 above, pp. 3-26.
} 
Foreign Office and the publicity he gave to the Near East on his return to London, plus his desire to see its "spiritual darkness" replaced by the "plans of Providence", contributed to the knowledge of conditions in the area. ${ }^{21}$

The presence in London of a Syrian named Assaad Yacoub Kayat further heightened interest in Syria and prepared the way for the SMAA. Kayat, a Greek Orthodox Christian, had learned English from the American missionaries in Beirut and had served as interpreter to the British consul in Damascus before making two journeys to London, the second from 1838 to 1840. Exposure to Western life led Kayat to decide to "work for the Glory of God and benefit of Syria" by introducing Protestantism and modernization to his native land. In London he sought the assistance of the British and Foreign Bible Society, the missionary societies, and other church groups. Many who heard his appeal were those who were to receive Peter Parker in 1841. Kayat stressed education for girls, and while in England he organized the Society for Promotion of Female Education in the East through which funds and books could be channelled. With help from the Bible Society and the Church Missionary Society, he returned to Beirut early in 1840 having stimulated an interest in providing education, religious tracts, and other civilizing measures for the area. ${ }^{22}$

Thus a confluence of benevolent Englishmen and foreign visitors in London at a time of increased confidence in the benefits of Western medicine heightened interest in Syria and inspired the creation of the SMAA. A letter of encouragement written to the organizers from Syria on 2 September 1841 suggests that plans had been formulated some time during the previous summer. ${ }^{23}$

In the style typical of nineteenth-century philanthropies, the SMAA had a list of patrons whose social status lent prestige to its endeavours. In addition to the Marquess of Bristol, the Earl of Chichester, and the Earl of Gainsborough, patrons included the orientalist and diplomat, Sir Gore Ouseley, the prominent banker, Sir Thomas Baring, Sir George H. Rose, MP, and Admiral Sir Robert Stopford, who had commanded the

\footnotetext{
${ }^{21}$ William Holt Yates, MD Edinburgh, 1825, Cantab. 1831, London 1839, consulting physician to the Royal General Dispensary, founded the Syro-Egyptian Society of London in 1844. See London Medical Directory, 1846, pp. 171-172. Also Public Record Office (PRO) FO 78/464, Wm. Holt Yates to Lord Palmerston, 2 January 1840 [1841]; William Holt Yates, MD, The modern history and condition of Egypt, its climate diseases and capabilities, 2 vols., London, Smith Elder, 1843.

22 For Kayat's biography, the sources are his own writings which though self-serving contain a fascinating account of his early life. See Koolee Meerza Najef, Journal of a residence in England and of a journey from and to Syria, written in Persian by H.R.H. etc., translated and with explanatory notes by Assaad Y. Kayat, 2 vols., printed for private circulation only by Wm. Tyler, [n.d.]. This describes the travels of three Persian princes, accompanied by Kayat, to England where they sought government aid in freeing their father from the Shah's prison. Assaad Y. Kayat, A voice from Lebanon with the life and travels of Assaad Y. Kayat, London, Madden, 1847, is a fuller biography and includes Kayat's experiences during a subsequent third visit to London at which time he studied medicine at St George's Hospital and became a member of the Royal Society of Surgeons. He also published The eastern traveller's interpreter; or Arabic without a teacher, London, James Madden, 1844. See also Kamal S. Salibi, 'The two worlds of Assaad Y. Kayat', in Benjamin Braude and Bernard Lewis (editors), Christians and Jews in the Ottoman Empire, New York, Holmes \& Meier, 1982, vol. 2, pp. 135-158; British and Foreign Bible Society, Foreign Correspondence Inwards, 1838/No. 2, letter \#177, 12 June 1838; 1838/No. 3, letter \#6, 2 July 1838; 1840/No. 1, letter \#42, 27 January 1840; 1841/No. 4, letter \#37, 1 September 1841; Missionary Register, 1843, p. 87.

${ }^{23}$ Syrian Medical-Aid Association, pamphlet, n.d. [1842], S.O.A.S., CCWM 01/2, Pams. 35, note 13 above, letter from Rev. W. M. Thomson, an American missionary in Beirut. This letter and other portions of the pamphlet appeared in slightly altered language in Missionary Register, 1842, pp. 136-137.
} 
British fleet in the eastern Mediterranean. Rev. Baptist Noel, one of London's more popular evangelicals, was also a patron, as were Sir Henry Halford, President of the Royal College of Physicians, and Sir James Clark, Physician to the Queen. ${ }^{24}$ But it was the Committee that expected to do the real work of the organization. Its members included a Member of Parliament, three clergymen, and four medical men, James T. Conquest, Charles J. B. Williams, William Holt Yates, and Thomas Hodgkin. ${ }^{25}$ From all accounts, Sir Culling Eardley Smith had been the primary instigator of the project, assisted by Hodgkin. ${ }^{26}$ Sir Culling was also the most generous contributor, initially donating $f 100$ (a substantial sum at that time) and repeating that gift several times over the next few years. Kayat and his wife, back in Beirut by 1841 , subscribed a smaller amount. ${ }^{27}$

The primary purpose of the SMAA was to provide free medical care in Syria. The organizers had been told that there was not "a single resident practitioner to be found (possessing the slightest claim to respectability) from Gaza to Antioch, from Hebron to the Haouran, or from Beyrout to Damascus, Homs and Hamah" and that the inhabitants relied on charm vendors, miracle mongers, fakirs, and sorcerers for cures. ${ }^{28}$ "Whenever an European who practices medicine appears, his steps are

\footnotetext{
24 In an address to his colleagues at the Royal College of Physicians in 1838, Sir Henry Halford had proposed medical men as missionaries to foreign lands where "the cure of diseases ... must be likely to facilitate the introduction of our knowledge, and add most humanely to their civilization, and not to their temporal happiness only, but to their future felicity, by the introduction of the holy Scriptures amongst them, by this avenue." Quote from Parker, op. cit., note 11 above.

${ }^{25}$ W. F. Cowper, MP, the step-son of Lord Palmerston, was active in promotion of legislation for reform of the medical profession. The four doctors were friends and were associated in other reform and philanthropic activities. For Conquest, see London Medical Directory, 1846, p. 34. Also, Charles J. B. Williams, Memoirs of life and work, London, Smith, Elder, 1884. For Hodgkin see Edward H. Kass, 'Thomas Hodgkin, Physician and social scientist', Guy's Hosp. Rep., 1966, 115: 269-280; Michael Rose, Curator of the dead, Thomas Hodgkin (1798-1866), London, Peter Owen, 1981; Amalie M. Kass, 'Friends and philanthropists: Montefiore and Dr. Hodgkin', in S. and V. D. Lipman (editors), The century of Moses Montefiore, Oxford University Press, 1985, pp. 71-103; A. M. and E. H. Kass, 'Thomas Hodgkin, M.D., a reappraisal', Guy's Hosp. Gaz., 1985, 99: 259-264, 293-300, 343-349.

${ }^{26}$ SMAA prospectus, op. cit., note 1 above; Lindfield Reporter, 1842, 4: 239-40; Yates, op. cit., note 21 above, vol. 2, p. 40. Yates does not mention Hodgkin as one of the men who aided Sir Culling but refers instead to "Rev. Baptist Noel, Honorable W. Cooper [Cowper?] Major Harvey and others." Dr Williams mentions Sir Culling and Dr Conquest and also says Dr George Whitely was sent to Beirut as "the first medical missionary", which indicates the confusion in purposes of the SMAA but is otherwise enigmatic, note 25 above, p. 273.

${ }^{27}$ SMAA, op. cit., note 23 above.

${ }^{28}$ Lond. med. Gaz., 1842-3, 31: 905-908; Lancet, 1842-3, i: 867. This was not entirely accurate. Missionaries sent to Jerusalem by the London Society for the Promotion of Christianity amongst the Jews (LJS) had provided simple medical care in an earlier period and, simultaneously with creation of the SMAA, plans were underway for another agent of the LJS, Dr McGowen, to accompany Bishop Alexander who was to inaugurate an Anglican diocese in the Holy City. Dr Yates acknowledged McGowen's potential work when writing about the SMAA to the London medical press. The Americans also had a medically trained missionary, Dr Cornelius Van Alen Van Dyck, in Beirut by 1840. The British were contemptuous of Italian and Polish doctors present in Syria and seemed ignorant of the efforts of the Egyptians to promote medical progress during the eight years they controlled the area. See Tibawi, op. cit., note 4 above, p. 12-13, 84, 115; Leila Tarazi Fawaz, Merchants and migrants in nineteenth-century Beirut, Cambridge, Mass., Harvard University Press, 1983, pp. 33-34; Lutfi M. Sa'di, 'Al-Hakim Cornelius Van Alen Van Dyck (1818-1895)', Isis, 1937, 27: 20-45; A. L. Tibawi, A modern history of Syria, London, Macmillan, 1969, pp. 87-89; Lancet, 1843-44, i: 758. Despite his medical degree, Van Dyck was more interested in education and devoted much of his time to translation of textbooks.
} 
thronged with eager applicants, and his person is sacred even to the predatory Arabs." 29 Rev. W. M. Thomson, an American missionary stationed in Beirut, had also provided the founders with an encouraging forecast.

\begin{abstract}
[It is] a plan for doing good to Syria less liable to objection than any other, and must be favourably entertained by every rational mind of every sect in the land. It will alleviate much bodily suffering, soften the violence of prejudice, and conciliate favour; and will raise the demand for higher medical qualifications, more certainly and rapidly than any thing I can think of .... A dispensary for the gratuitous distribution of medicine will be a most excellent charity to the country. Many people die because their relations are too poor to purchase the most common medicines. ${ }^{30}$
\end{abstract}

The initial plan was to send one doctor, possibly with an assistant, and a supply of drugs and equipment. In time, the SMAA hoped to enlarge the number of British doctors, train native doctors, and open a hospital. The presence of scientifically trained personnel in a hitherto unstudied area was expected to add to medical knowledge and thereby to increase the possibility of preventing and treating plague and other diseases "which yearly destroy thousands in Syria and the adjoining countries."31

In addition to the improvement of health, the SMAA had several other goals which mirrored the spirit of the era but eventually served to confuse its operations. Although it was not affiliated with any sect or missionary society, the lay evangelicals and clergymen on the Committee clearly had a secondary agenda. The doctor they sent to Syria was not expected to make any direct missionary efforts, but it was "considered indispensable that he should be a person of a decidedly Christian character, who would thankfully avail himself of every opportunity to invite those, whom he might find favourably disposed, to have recourse to the SAVIOUR - the Physician of Souls."32 The Christian benevolence manifested by medical care would "win a favourable hearing" for subsequent missionaries "who shall come to teach the divine principles."

As patriotic Englishmen, the members of the SMAA hoped that Britain's "national character [would] be favourably exhibited" by their charitable enterprise. The warlike image acquired during the recent hostilities would be dispelled when "gentle accents of pity and relief" displaced the "roar of the cannon and cries of the wounded." 33 Grateful Syrians were expected to favour British political influence and welcome British commerce. The SMAA also intended to promote social improvements in Syria by introducing Western ideas of cleanliness, nutrition, and child care and by working with Kayat, with other agents of the Syrian Education Society, and with kindred groups. In short, medical aid was the means by which the benefits of Anglo-Saxon civilization would be diffused among a deprived and depraved people. In the words of the prospectus for the SMAA, "A holier and more beneficient crusade is now submitted to the friends of Syria and of the Cross, than that for which myriads of Englishmen once abandoned their families and their country, and a brother of the

\footnotetext{
29 Lindfield Reporter, op. cit., note 26 above.

30 See note 23 above.

31 SMAA, op. cit., note 23 above.

32 Ibid.

33 Ibid.
} 
Sovereign of England mortgaged the crown of Normandy." 34 It remained to be seen if the SMAA would be any more successful than was King Richard.

In its initial phase, these high-minded prospects inspired strong support from other benevolent Englishmen eager to bestow "the blessings of medical skill" on the needy Syrians. In the first year, $£ 752$ was raised by subscription and donations. ${ }^{35}$ Forty physicians applied to be sent to Syria. Dr Thomas Kerns, thirty-eight years old, from Westport, Ireland, was selected for the post. He and his wife set sail for Beirut in early summer 1842, the British government defraying the major part of the cost of passage through the influence of Admiral Stopford. ${ }^{36}$ Dr and Mrs Kerns arrived in Beirut on 21 June 1842. Assaad Kayat had been alerted to the plan, and despite his personal opposition to an association that would be competing with him for funds and support in England, he welcomed Dr and Mrs Kerns to Syria, arranged to rent space for the dispensary, and engaged an interpreter. Not only were the Kerns unprepared for an Arabic-speaking land, but, like many strangers abroad, they were also dissatisfied with the food. Kayat felt compelled to serve them soup and mutton instead of the traditional fish and rice. ${ }^{37}$

Kerns faced problems more serious than personal adjustment to life in Beirut. As the most important city politically and economically on the Syrian coast, Beirut had already acquired an international flavour, with foreign consuls, American missionaries, French and British traders, and Greek and Italian shopkeepers enjoying the natural beauty and commercial potential of its superb location. ${ }^{38}$ It was also suffering from the effects of recent clashes between the Maronites and Druze. ${ }^{39}$ Kerns feared that the civil disorder and prejudice against Christians might be detrimental to his work. However, he assured his employers in London that the dispensary had started out well. During the first three months in which he recorded cases, he had treated 1297 patients. He was especially gratified that

my patients consist not only of every Christian sect in the country, but also of Mohammedans, Jews, and the Druses of Lebanon; and, as a pleasing evidence that the people appreciate the advantages which British benevolence has placed within their reach, I may notice that, even under the seclusion which custom has imposed upon the females of these countries, and the reluctance with which they usually approach strangers, among the applicants at the dispensary, we have had a larger proportion of females than males. ${ }^{40}$

${ }^{34}$ Ibid.

${ }^{35}$ Lancet, 1842-3, ii: 454.

${ }^{36}$ Med. Times, 1845, 12: 51.

${ }^{37}$ Kayat (1847), op. cit., note 22 above, pp. 284-287. Kayat wrote that he "hired a house", which I presume to mean a building for the dispensary because Kerns was reported to be living in Kayat's house in the spring of 1843 when the latter had returned to London seeking support for his educational programme and attending medical school himself. See Hodgkin to [Sir Culling Eardley Smith], 29 March 1843, 18:42, note 11 above.

${ }^{38}$ Fawaz, op. cit., note 28 above, pp. 24-27; Philip K. Hitti, A short history of Lebanon, London, Macmillan, 1965, p. 189. Albert Hourani, Arabic thought in the liberal age, Cambridge University Press, 1983 , pp. 51-63, is a valuable study of European influences on Syria during this period.

${ }^{39}$ Fawaz, op. cit., note 28 above, pp. 21-23; Hourani, op. cit., note 38 above, pp. 62-63.

40 Lancet, 1842-3, i: 867-870. 


\section{Amalie M. Kass}

For the first twelve months, from September 1842 to September 1843, he reported that the total number of patients was 4298, an impressive number for a doctor who did not speak the native language and had to overcome suspicion and distrust. He assured his backers that not only were all faiths and both sexes represented, but also all classes: pashas, sheikhs, camel drivers, and peasants. Some had travelled great distances under extreme hardship to take advantage of Kerns' presence. The pashas and sheikhs were more likely to have been treated at home, which would have added to Kerns' busy schedule.

The SMAA had no way of verifying Kerns' reports, but what he had written certainly seemed to justify their efforts and they forwarded his accounts to the Lancet, the London Medical Gazette, and the Medical Times, which reprinted the reports for the information of colleagues and hopefully for the benefit of the association. ${ }^{41}$ Diseases of the eye comprised more than a quarter of the cases, followed by fevers, rheumatism, ulcers, and bronchitis. The statistics were accompanied by remarks about the various diseases Kerns had seen and treated and contain an interesting, if outdated, understanding of their aetiology. For example, with regard to ophthalmia, which included every eye disease from simple conjunctivitis to ulceration or opacity of the cornea,

The disease, if neglected, or improperly treated, rapidly runs its destructive course, and the treatment adopted by the natives being mere quackery, the lamentable results are to be seen everywhere .... Exposure by sleeping in the open air, poverty, and want of cleanliness, have each, in turn, been named as the cause; but ... I am inclined to think that exposure to the unsubdued light of the sun, arising from the peculiar head dress, is amongst the most fruitful causes of this disease.

Intermittent fever (malaria) posed another mystery.

Marsh miasmata is out of the question where the land is parched with drought one half of the year, and at no period, in this district, are marshes or stagnant pools to be found of any extent; however, if we omit the association of marsh, which is but a casual circumstance, the theory of decomposed animal and vegetable matter will remain as probable as any other, and as applicable.

He considered urinary infections to have arisen from excessive use of unripe fruit, and dyspepsia to be caused by "the very large proportion of vegetables cooked with oil, which constitutes the food of the natives, and from the habit of eating unripe fruits." On the positive side, he reported that dropsy was rare, hare-lip and club foot deformities uncommon, and pulmonary consumption infrequent. The cases of syphilis which he had observed, designated by the natives "Habbeh Frangee"-the "Frank disease" (or "Button"), were generally mild. Moslem injunctions against alcohol reduced the frequency of liver disease. Though Kerns' reports were hardly indicative of the total population, they provide an insight to those things which came his way and excited his curiosity.

Kerns also reported on his treatment of the various disorders that had come to his attention. He had operated on ten cataract cases with varying success, and had used

${ }^{41}$ For Kerns' first year report, see ibid., 1843-44, i: 755-759; Med. Times, 1844, 9: 270-271, 291; Lond. med. Gaz., 1843-44, 33: 565-569. 


\section{The Syrian Medical Aid Association}

electricity or electro-magnetic influence on paralysed limbs. Trusses sent by the committee in London gave relief to hernia patients, while the drugs he had brought with him and additional supplies that were forwarded from England enabled him to treat the fevers, ulcers, etc. His services, and the treatment he provided, were available without charge except to the Europeans in Beirut who could be assumed able to pay. Kerns raised the possibility of charging the wealthier Syrians too. The London Committee advised him to use his own discretion, pointing out that if and when a hospital were opened, there might be a local Board of Governors, in the British style, whose financial support would entitle them to recommend patients for free care. ${ }^{42}$

Finally, Kerns appended "thermometrical tables" to his reports, providing average monthly temperatures and rainfall from several stations. This information was intended to enable his readers to correlate climatic factors with the occurrence of disease. Dr William Holt Yates, who forwarded Kerns' reports to the medical journals on behalf of the SMAA, could not refrain from adding comments which reflected his personal view of life in the Near East.

In Mohammedan countries disease is believed to have been sent by "Allah" as a punishment for sin, therefore it is accounted presumptious to attempt to eradicate it; but if a "Hakkim" [wise man] passes by, the afflicted kiss the hem of his garment with superstitious veneration, and beseech him to "lay on his hands on them and heal them" ... they have no notion that the "art of healing the sick" may be acquired or taught.

No wonder Yates and other other members of the SMAA expected "these hitherto deluded beings [to] become devoted to their benefactors."

The SMAA held its second anniversary meeting on 20 June 1843 at the Music Hall, near Tottenham Court Road. Lord Ashley, later Lord Shaftesbury, presided. It was the highpoint in the short history of the organization. A surplus of $£ 250$ remained from the first year, and there were plans to seek additional funds for construction of a hospital in Syria. The Lancet praised the work of the association and recommended it to its readers. 43

As secretary of the SMAA, Thomas Hodgkin maintained an active correspondence with Kerns. Hodgkin bolstered Kerns' spirits, answered his queries, and offered advice on everything from manufacture of distilled water to ways of dealing with the Syrians. Hodgkin cautioned Kerns to make great allowance for cultural differences but warned that he must also use firmness in order to command respect. ${ }^{44}$ Kerns was frequently admonished for not sending livelier reports, with case histories and results that could be used to promote the association and gain additional support. To Hodgkin, it was quickly apparent that the initial surge of enthusiasm was waning. An appeal to the Governors of St George's Hospital printed with the sanction of the medical officers of that institution had been remarkably unproductive of funds. ${ }^{45}$ Assaad Kayat, who had returned to England for the third time to assist a group of Syrian medical students and

42 Hodgkin to Kerns, 2 January 1843, 18:23, note 11 above.

43 Lancet, 1842-3, ii: 454.

44 Hodgkin to Kerns, note 42 above; Hodgkin to Kerns, 27 November 1842, 18:11, note 11 above.

45 Hodgkin to Kerns, note 42 above; Hodgkin to [Sir Culling Eardley Smith], 9 January 1844, 18:168, note 11 above. 
to begin his own medical education, was no longer helpful to the SMAA. To the contrary, he was campaigning for his own projects among the same pool of potential supporters. ${ }^{46}$ Several of the original officers of the SMAA had abandoned their positions, leaving Hodgkin as sole secretary and ticasurer. Sir Culling was frequently out of the country and when he was home he was busy with newer causes which now engaged his attention. Hodgkin and Dr Yates were often the only attenders at committee meetings. ${ }^{47}$

In the spring of 1844 , Dr Kerns surprised the Committee by announcing his intention to resign from the SMAA in order to pursue a more evangelical career with the Society for the Promotion of Christianity amongst the Jews. Despite the success of his Beirut dispensary, the possibility of a hospital in Damascus, and continued encouragement from London, either Kerns was an unfulfilled missionary who found working for the SMAA to be too heavily weighted on the medical side or he feared that the future of the organization was uncertain.

Kerns' decision caused a distressed Hodgkin to write to the Jews Society asking them to help the SMAA meet the expense of sending a replacement to Syria, although the rest of the committee was probably less disturbed by Kerns' defection to a cause many of them supported. ${ }^{48}$ Hodgkin was also troubled by the thought that the people in Beirut and environs who had come to expect medical treatment at the dispensary of the SMAA might be abandoned. Such conduct would hardly be fair to the patients and certainly would not contribute to Britain's honour. ${ }^{49}$

It was not difficult for the SMAA to replace Kerns. Again there were many applicants for the post, which paid $£ 200$ per annum in addition to house rent. Dr James B. Thompson, who had been the second choice at the time of Kerns' selection, received the appointment. Thompson had had experience as a surgeon with the Colonial Land and Emigration Commission in Polynesia and was presently physician at the Royal General Dispensary in London. Unlike Kerns, Thompson's interests were strictly medical. He viewed himself as "a missionary of medical science and of civilization". Thompson was unmarried. Antonius Ameuny, one of Kayat's protégées, agreed to curtail his medical studies in London and return to Syria as Thompson's interpreter and assistant. ${ }^{50}$ They were to proceed to Damascus where Kerns had investigated the possibilities for an SMAA dispensary and hospital.

\footnotetext{
${ }^{46}$ Hodgkin to [Sir Culling Eardley Smith], 29 March 1843, 18:42, note 11 above. See also Missionary Register, 1845, p.93-94; A. Y. Kayat to J. B. Braithwaite, 24 June 1843, Friends House Library, Temp. MSS. $12 / 1$.

${ }^{47}$ Hodgkin to [Sir Culling Eardley Smith], 9 January 1844, note 45 above.

${ }^{48}$ Hodgkin to Sir Culling Eardley Smith, 3 April 1844, 18:204; Hodgkin to Kerns, 3 April 1844, 18:203, Hodgkin to the Secretary, Society for Promotion of Christianity amongst the Jews, 1 May 1844, 18:213, all note 11 above. Kerns became an agent of the Jews Society, was ordained in the Anglican church and spent several years at missionary posts in Syria before his wife's ill health forced them to return to England. See Missionary Register, 1847-8, p. 83; Gidney, op. cit., note 16 above, p. 247; London Society for Promoting Christianity amongst the Jews, 37th Annual Report, p. 18.

${ }^{49}$ Hodgkin to Kerns, 3 April 1844, note 48 above; Hodgkin to Kerns, 28 May 1844, 18:217, note 11 above.

${ }^{50}$ Hodgkin to Dr Alison, President, Medical Missionary Society, Edinburgh, [n.d.], 18:198; Hodgkin to Dr Keith, 1 May 1844, 18:212; Hodgkin to Sir Culling Eardley Smith, 3 May 1844, 18:214; Hodgkin to Kerns, 5 May 1844, 18:215; Hodgkin to Kerns, 28 May 1844, 18:217, all note 11 above; PRO FO 78/762, James B. Thompson, AB, MD, British Hospital Damascus to Viscount Palmerston, 29 March 1848; for the Thompson quotation, see Lancet, 1844, i: 288.
} 
The strong presence of American missionaries and European merchants in Beirut may have led the Committee to decide that Damascus offered better opportunities for British medical philanthropy and for the promotion of the other interests of the SMAA and that there would be greater support at home if they relocated their operations. ${ }^{51}$ Kerns had had to compete with two American missionary doctors who were now installed in Beirut, whereas Damascus was said to be without a "proper" doctor. 52 "By the by", wrote the editor of the Lancet, "what an El Dorado this city of Damascus must be (in a practical point of view, we mean) to a London physician! One hundred and fifty thousand inhabitants, and no rival." 53

Thompson arrived in Damascus in July 1844 and was soon sending reports back to London which were even more enthusiastic than Kerns' had been.

\begin{abstract}
We have all sects visiting us, and some of the chief Moslem families, the true descendants of the Prophet; we have even gone so far as to get them to look at dried preparations and anatomical plates, which no person, knowing their prejudices on these matters a few years ago, could suppose we should have brought about such a change, and cause them to feel and express an interest in these inquiries. ${ }^{54}$
\end{abstract}

Thompson regretted that it was not possible to attract surgical patients because "they have a horror of the knife as yet". However, he was very busy. In addition to work in the dispensary, he had begun to arrange for obstetrical service in the native quarters, and had visited two leper asylums which seemed so badly supplied that he gave money for the purchase of bread and sent mutton for a "nourishing soup". It was distressingly apparent to him that nutrition was as serious a problem as direct medical care.

In December, Thompson described one of his more exotic experiences.

\begin{abstract}
Since my last Letter I have had the honour of prescribing for the Queen Dowager of Persia, a very old lady, and I could only see the tongue and feel the pulse of my royal patient, so closely and scrupulously was Her Majesty veiled from my view: and, still more strange, this privilege was only allowed me through her bed-room doorway, she sitting, or rather in the semi-erect position, attended by her waiting maid, or lady of the bed-chamber. However, under these many disadvantages, I am happy to say my royal patient is now better.
\end{abstract}

Thompson also revealed that "the ladies in the harem latterly unveil themselves to me, and ask me sometimes to sit down and partake of coffee and a pipe with them, which request is tantamount to a command." 55 Thompson informed his supporters that during the full year of 1845 he had treated 8137 cases, nearly double the number

${ }^{51}$ Damascus was well located on the overland trade routes through Iraq and Iran to India. See Fawaz, op. cit., note 28 above, p. 62, and Hodgkin to Kerns, 2 November 1843, 18:136, note 11 above.

52 Missionary Register, 1845, p. 92. The two Americans were Dr VanDyck (note 28 above) and Dr deForest, both medical missionaries connected with the American Board of Commissioners for Foreign Missions. See Edinburgh Medical Missionary Society, Third annual report, 1845, printed by Andrew Jack, S.O.A.S., CCWM 01/2, Pams.35.

${ }_{53}$ Lancet, 1844, i: 288-291. It is unlikely that the population of Damascus was as large as suggested by the Lancet.

${ }^{54}$ Med. Times, 1845, 12: 51 ; also in Missionary Register, 1845, p. 92, letter from Thompson dated 8 November 1844, with the wording slightly altered.

${ }^{55}$ Missionary Register, 1845, pp. 92-93, letter from Thompson dated 8 December 1844. 
Kerns had seen during his first twelve months in Beyrout. ${ }^{56}$ The prevalence and distribution of diseases was not much different from that reported by Kerns. ${ }^{57}$

Despite this apparent success, Thompson was in trouble from the beginning, partly because of his own personality, partly because the SMAA was disintegrating. A "Ladies' Benevolent Association for Syria and the Holy Land" had been established in June 1844, just at the time Thompson was departing from England. It was meant to co-operate with the SMAA "in affording Comfort and Relief to the Sick OF ALL NATIONS, the aged, and the indigent blind, in Syria and Palestine." Mrs Holt Yates was secretary. ${ }^{58}$ But the combined efforts of the ladies and the stalwarts remaining with the SMAA were not sufficient. Hodgkin found it necessary to meet current expenses from his own pocket, hoping for later reimbursement. Though drug companies charged wholesale prices and every possible means was taken to reduce shipping costs, Thompson's salary, rent, and expenses were beyond the capacity of the two organizations. In December 1845, Hodgkin warned Thompson that the SMAA was terminating and advised him to prepare a final accounting. ${ }^{59}$ Thompson was unwilling to give up so easily, and for another year the association managed to raise sufficient funds to meet his bills. ${ }^{60}$ However, in March 1847, Thompson was told that the committee was defunct. ${ }^{61}$ It could not even pay for his return to England.

The economic distress and political tensions that preceded repeal of the Corn Laws in 1846 undoubtedly made it difficult to sustain interest in foreign charities such as the SMAA, although its support had come from a select group which could have remained more faithful had they wished. More significant factors in its demise were the religious differences within the Committee. The first treasurer resigned after a brief tenure in the office when he realized that all the members were not Church of England. ${ }^{62}$ Sir Culling became disenchanted when, during his absence from England, instructions were issued to Thompson which de-emphasized the evangelical aspect of the association. ${ }^{63}$ Hodgkin was charged with responsibility for this change in policy, and relations between him and Sir Culling became decidedly cool. Hodgkin, a Quaker, was sensitive to the accusations, but it is likely that there was a measure of truth to them, for he was more interested in providing medical care and promoting Western civilization than he was in active proselytizing. As the number of participants at Committee meetings dwindled, Hodgkin inevitably became more influential. In the end, it was he alone who sustained Thompson. In 1849, three years after the SMAA had passed out of existence,

\footnotetext{
${ }^{56}$ Missionary Register, 1846, p. 96.

${ }^{57}$ PRO FO 78/762, 'Jerusalem, Damascus and Lebanon, the Hospital at Damascus', printed from Galignani's Messenger, 24 February 1845 and included with James B. Thompson to Lord Palmerston, 29 March 1848.

58 The Ladies' Benevolent Association, etc., London, William Watts, 1845. This pamphlet contains greatly expanded lists of patrons and committee members for the SMAA, which suggests that there was an unsuccessful effort to raise funds through this scheme.

${ }^{59}$ Hodgkin to [Thompson], 15 November 1845, 12:159; Hodgkin to [Thompson], 5 December 1845, 12:165, both note 11 above.

60 Hodgkin to [Thompson], 6 February 1846, 12:170; Hodgkin to [Thompson], [?] April 1846, 12:171, both note 11 above.

${ }^{61}$ Hodgkin to [Thompson], 3 March 1847, 12:186, note 11 above.

${ }^{62}$ Hodgkin to Sir Culling E. Eardley, [n.d.], 13:62, note 11 above. (Smith changed his name to Eardley, his mother's family name, in 1847.)

${ }^{63}$ Hodgkin to [Thompson], 3 March 1847, 12:186, Hodgkin to [Thompson], 1 May 1849, 13:38, both note 11 above.
} 
Hodgkin personally paid $£ 60$ on Thompson's behalf while complaining that all his West End practice "could not cover the deficit I am stuck with in Sir C. E. Smith's enlisting me in his SMAA." 64 According to Hodgkin, Sir Culling was responsible for initiating grandiose plans and then moving on to another cause, leaving others to suffer the effects. ${ }^{65}$ In all fairness, Sir Culling was only one of the many who had embraced the SMAA in its early days and then had abandoned it. Dr and Mrs Yates, for example, returned to Syria, where they acquired property and became involved in an unsuccessful enterprise for cultivation and manufacture of silk. ${ }^{66}$

Despite the demise of the SMAA, Thompson was determined to remain in Damascus. He too liked that part of the world and he had his own dreams for creation of a hospital and medical school. He must have realized that the SMAA could not be counted on as a permanent sponsor. Even before he left England, he had turned to the British government for support. The Foreign Office supplied him with a few letters of introduction. Shortly after his arrival in Syria, Thompson wrote to Lord Aberdeen to apprise him of his intention to open a twelve-bed hospital and to give medical instruction to native students. ${ }^{67}$ The doctor offered to relay information about conditions in Syria for the use of the Foreign Office. While Hodgkin was struggling to find additional funds to meet Thompson's expenses, the latter began to ask the government for financial assistance so that the "British Hospital in Damascus" might continue to "remove prejudice and fanaticism" and to win the friendship of the Syrian people. ${ }^{68}$ Unfortunately for Thompson, the Foreign Office sought the opinion of its consul in Damascus, who reported that the doctor's claims to be operating a hospital and medical school were exaggerated and that the political advantages of his activities were "very slender and nugatory". ${ }^{69}$ Lord Aberdeen denied Thompson's request.

Faced with dwindling funds from the SMAA, Thompson resorted to charging his wealthier patients. His fees exceeded those of other foreign doctors in Damascus, ${ }^{*}$ and when patients did not pay, he turned to the British consulate for assistance. This created an awkward situation, which was resolved when the Foreign Office forbade its agents to act as a collection service. ${ }^{70}$ Thompson further antagonized the Damascenes and foreign community by his ostentatious style which included use of "an armed attendant with a Silver Stick" who aroused jealousy and suspicion..$^{71}$ As if his situation were not already delicate, he created additional difficulties by accidentally shooting a Moslem in the leg while firing at a dog, and then refusing to compensate the man for medical care and lost wages. ${ }^{72}$

${ }^{64}$ Hodgkin to [Thompson], 1 May 1849, 13:48, note 11 above.

${ }^{65}$ Hodgkin to [Thompson], 3 March 1847, 12:186, note 11 above.

${ }^{66}$ Yates to Hodgkin, 31 October and 6 December 1847, 5:232, note 11 above.

${ }^{67}$ PRO, FO 78/585, Thompson to Lord Aberdeen, 10 July 1844.

${ }^{68}$ PRO, FO 78/627, Thompson to Lord Aberdeen, 8 May 1845; FO 78/622, Foreign Office to Consul Richard Wood, Damascus, 7 June 1845.

${ }^{69}$ PRO, FO 78/622, Wood to Henry Addington, 2 July 1845; FO 78/627, Foreign Office to Thompson, 7 August 1845 .

*Despite the claims of the SMAA, there were Italian and Polish doctors in Damascus. Yates and Kerns considered them to be "mere quacks". See Med. Times, 1843-4, 9: 292; Lancet, 1843-4, i: 758.

${ }_{70}$ PRO, FO 78/622, note 69 above; FO 78/660A, Wood to Aberdeen, 3 February 1846; FO 78/660B, Foreign Office to Wood, 17 March 1846.

${ }^{71}$ PRO, FO 78/622, note 69 above.

${ }^{72}$ PRO, FO 78/660A, Wood to Aberdeen, 8 January 1846, 3 February 1846 with enclosure. 
Thompson persevered in his requests for financial support from the Foreign Office, citing the continued success of his hospital, where he claimed to be caring for 1200-1500 out-patients a month, some of whom were said to wait many hours at the door until they could be admitted. ${ }^{73}$ On one occasion, Thompson warned that the goodwill toward Britain which he had fostered was threatened by a physician sent to Egypt and Syria by the French ${ }^{74}$ Despite these pleas, Lord Palmerston, who was then Foreign Minister, agreed with his predecessor that there were not "sufficient grounds for recommending pecuniary assistance from Her Majesty's government." It was a sign of the complete effacement of the SMAA that Richard Wood, the British consul in Damascus who happened to be in London at the time that one of Thompson's requests were received, reported that though it was true that the doctor had been sent to Damascus by "some Philanthropic Society to establish a Dispensary for the poor ... I cannot now find out any trace of that Society."76

Thompson remained in Syria and joined Yates and several other Englishmen in the purchase of land and mulberry trees. However, his fortunes did not improve. Some of the partners were unscrupulous and the silk enterprise went bankrupt. ${ }^{77}$ Thompson had to defend himself against charges that he had misrepresented his accomplishments as a physician in Damascus and that he himself was guilty of poor conduct. On this occasion, however, the British consuls in Beirut and Damascus came to his aid, ruling against the defrauding partners and praising Thompson for performing his duties well as "chief officer of the dispensary in Damascus". The only trouble was "insufficient pecuniary support from the society in England that sent him."

What then were the accomplishments of the SMAA? For a brief time it reflected increasing certainty about the benefits of Western medicine and the obligation to transpose them to other parts of the world. It chose to operate in Syria where there seemed to be a genuine need for well-trained doctors. It sent two committed men who met the expectations of their sponsors by providing the best care possible under difficult circumstances. As a result, up to 20,000 persons were treated who might otherwise have had little if any care. Unfortunately, there was no one to carry on after

${ }^{73}$ PRO, FO 78/665, Thompson to Lord Palmerston, 3 December 1846.

${ }^{74}$ PRO, FO 78/762, Thompson to Palmerston, 29 March 1848.

75 PRO, FO 78/762, Addison to Thompson, 5 May 1848; FO 78/627, note 69 above.

${ }^{76}$ PRO, FO 78/715, Wood to John Bidwell, Foreign Office, 9 March 1847.

${ }^{77}$ C. E. Eardley to Hodgkin, 16 July ?[1849], 5:220; Hodgkin to Thompson, 2 October, 1849, 5:217; Hodgkin to Col. Rose, 1 October 1849, 5:216; Thompson to Hodgkin, 16 November 1849, 5:223, all note 11 above.

${ }^{78} \mathrm{~N}$. Moore to Hodgkin, 21 November 1848, 5:229, note 11 above. Thompson subsequently married Elizabeth M. Lloyd who had been a member of the "Syro-Egyptian Committee formed under the presidency of Sir Culling Eardley". They lived in London for a few years before going to Constantinople to promote Thompson's plan for a railroad to India via the Euphrates. From Constantinople, they returned to Suedia in Syria where Thompson continued to hold property and remained there until the outbreak of the Crimean War. Thompson reached Balaclava but was refused a military commission. However, he contracted a "raging malignant fever" and died in Turkey. In 1860, when civil war erupted in Lebanon between the Druze and Christians, Mrs Thompson went back to Beirut where she helped with relief efforts and started a charity which eventually came to be known as the Syrian Mission. It was primarily devoted to education for girls. See H. B. Tristram, Daughters of Syria, London, Seeley, Jackson \& Halliday, 1872, pp. 27-47; Tibawi, op. cit., note 4 above, pp. 156-157. 
Thompson, and the permanent effect of the SMAA was negligible. As a secular organization dedicated to medical aid in Syria, the SMAA had no direct heirs. ${ }^{*}$

Though their intentions were noble, the men who created and supported the association in its first year misjudged the realities of the situation in Syria and in England. Their fond hopes that "such a fine country degraded by the character of its inhabitants and of its neighbours" could be significantly improved by the efforts of well-meaning foreigners were bound to meet disappointment. ${ }^{79}$ The expectation that their society would expand its membership and funds was unfortunately predicated on the sustained participation of the officers and Committee and continued philanthropic interest in a Syrian charity. Consul Wood estimated that between $£ 1200$ and $£ 1500$ per annum would be needed to maintain adequately a hospital in Damascus, and he suggested that if the British government were to participate in such an enterprise it must control the conduct of the medical officer and the general operation of the facility. ${ }^{80}$ The SMAA was never able to raise such large sums of money and was unable effectively to monitor its agents in Syria.

The multiple aims of the SMAA also contributed to its failure. The early evangelical emphasis and the desire to rectify misdeeds of the past and improve Britain's "image", added religious and nationalistic overtones to a benevolent mission which then had to be judged for its non-medical accomplishments. This confusion of purposes created internal difficulties for the officers and made it harder to maintain public support. Clarity of purpose, more reasonable expectations, knowledge of the area and the people to be served, and sustained commitment might have made the SMAA more successful than it was and might have enabled it to make a more lasting contribution to the people in Syria.

\section{ACKNOWLEDGEMENTS}

I am grateful to Dr Edward H. Kass and Professor Edward V. Gulick for their helpful suggestions.

*The American University of Beirut, founded in 1866 as the Syrian Protestant College, was the outgrowth of the American missionary movement in the area. See Tibawi, op.cit., note 4 above, p. 202.

${ }^{79}$ Hodgkin to Kerns, 13 November 1845, 12:160, note 11 above.

${ }^{80}$ PRO, FO 78/622, Wood to Addington, note 69 above. 